JELTL (Journal of English Language Teaching and Linguistics)

e-ISSN: 2502-6062, p-ISSN: 2503-1848

2020, Vol. 5(2)

www.jeltl.org

\title{
Morphosyntactic Analysis of Political News on Online Tempo
}

\author{
Pertiwi Rini Nurdiani \\ IAIN Samarinda \\ e-mail:Pertivirininurdiani@gmail.com \\ Umar Fauzan \\ LAIN Samarinda \\ e-mail:umar.fauzan@iain-samarinda.ac.id
}

\begin{abstract}
Morphology and Syntax are very important studies in learning English. Morphology learns about how the words are structured and how they are put together from smaller part. It can be considered as the grammar of words. Meanwhile, Syntax discusses how the sentence is structured. The objectives of the research are to find out inflectional morphemes, derivational morphemes, and the patterns of clause structure which are found in political news on online Tempo in January 2019. This research used qualitative design and content analysis design where the source of data was article political news on Online Tempo in January, 2019. The major instrument of this research is the researchers themselves because they actively obtained and clustered the data and the secondary data was data sheet. The findings revealed three types of morphosyntactic, firstly, the researchers found 5 patterns of inflectional morpheme with 26 words. The most dominantpattern of inflectional morpheme was singular changing to the plural. Secondly, for derivational morpheme, it identified two types of classes including class-changing and class-mantaining. There were 3 patterns with 10 words in class-changing and 1 pattern with 1 word in classmantaining. The study also showed that the common pattern of derivational morpheme was class-changing pattern (verb to noun). Thirdly, there were 7 patterns with 15 clauses that were used in political news. The result of this study proved that the dominantpattern of clause structure was $S$ - $V$ - to Infinitive pattern with 4 clauses.

Keywords: derivation, inflection, morphosyntactic, morphology, syntax
\end{abstract}

\section{INTRODUCTION}

Linguistics is the scientific study of language (Lyon, 2002). Linguistics is highly important in language teaching as well as in language substance (Akan, Hassan, Islam, \& Abdelmajd, 2017; Briones, 2016; Irmayani \& Rachmajanti, 2017), in written or verbal forms (Kenstowicz, 2005; Mammeri, 2015; Ojanga, 2015; Sundari \& Febriyanti, 2020). Linguistics itself is divided into 2 branches, that are macro and micro linguistics. Macro Linguistics disscusses about psycholinguistic, sociolinguistic, and neurolinguistic. Then Micro Linguistics is a study about semantic, syntax, phonology, and morphology. In this research, the researchers discuss about morphology and syntax.

In Linguistics, Morphology refers to the mental system involved in word formation to the branch of linguistic that deals with words, the internal structure, and how they are formed 
Pertivi Rini Nurdiani, Umar Fauzan

(Aronoff \& Fudeman, 2001). Morphology is subfield of Linguistics that deals with the study of internal structure of words. Aronoff \& Fudeman (2001) stated that in Linguistics, Morphology refers to the mental system involved in word formation to the branch of Linguistics that deals with words, the internal structure, and how they are formed. The existance of morphological analysis has become one of strategy of vocabulary instruction, so that this kind of study is considered to be very important especially in language study (Bellomo, 2009). Thus, Morphology is the study of how the words are structured and how they are put together from smaller part.

Chomsky (1976) and Chomsky (2006) said that Syntax is the study of the principles and processes by which sentences are constructed in particular language. Then Miller (2002) stated that Syntax refers to how words are put together to build phrases, how phrases are put together to build clauses, and how clauses are put together to build sentences. Hence, Syntax is the way of sentence is structured. In other words, it is a way of words to combine each other to build a sentence (Finch, 2000).

Morphosyntax analysis consists of looking for the syntanctic category and the morphological decomposition of a word (Parisse \& Normand, 2000). In other words, morphosyntax reviews word order patterns and features (Dryer, 2008) as well as word forms (Goryainova et al., 2014). Alike with the theory from previous experts, Hijjo (2013) pointed out that morphosyntactic analysis is particulalrly investigating about word order and sentence structure.

An analysis of morphosyntax also can be found in the previous study by Budiharto in his thesis entitled Morphosyntactic Analysis on the University Students' Thesis Proposal in Madura (Budiharto, 2014), Nurlaili, Syntactical Error Analysis, in Second Semester Student's Writing of LAIN Tulung Agung (Nurlaili, 2015), Mashlahatulammah in her thesis entitled An Analysis of Derivational Afdfixes in a Journal Article of "Dinamika Ilmu" (Mashlahatulammah, 2018), Putri in her thesis entitled An Analysis of Derivation in Short Story Used by the Jakarta Post Online in Year 2017 (Putri, 2017), Aryati in her thesis entitled An Analysis of Derivational Affixes in the Land of Five Towers Novel by A. Fuadi Translated by Angie Kilbame (Aryati, 2014), Endang in her thesis entitled The Analysis of Derivational and Inflectional Morphemes in Lyric of Songs Adele Albums (Endang, 2014), and Wulandari in her thesis entitled The Analysis of Basic Sentence Pattern in English Translation of the Holy Qur'an in Surah Ad Dukhan by Abdulloh Yusuf Ali (Wulandari, 2015). Most of those studies focused on some processes in morph syntax in students' worksheets whereas, this study concentrated on analyzing political editorial.

Not only above studies, other studies which are in similar focus related to morphosyntactic analysis came from Ado \& Bidin (2017), Akan et al. (2017), Bellomo (2009), Caesar (2019), Darmawansah \& Indartono (2019), Dita (2010), Goryainova et al. (2014), Hijjo (2013), Kenstowicz (2005), Mainingrum (2018), Mammeri (2015), Nurhayati et al. (2017), Rashel (2010), Setyawan (2014), and Shu (2012).

Above all studies regarding with morphosyntactic analysis indicate that this kind of research is considered as a highly important study up to this era, yet also showed the issues of ignorance by surrounding people in using proper word order and sentence structure (Hijjo, 2013). Specifically, this research particularly investigates regarding with morphosyntactic analysis especially the syntactical and morphological categories. In this case, the syntactic category that the researchers analyze is the pattern of clause structure, whereas in terms of morphological categories, the researchers analyze derivational and inflectional morphemes. Unlike with previous studies, morphosyntactic analysis done by the researchers in this study is investigated on one of famous online newspapers what so called by Tempo. 


\section{LITERATURE REVIEW}

Morphology is the part of Lingusitics that studies the grammatical properties of words and how words are related to each other in language. Indeed, the central task of Morphology is to study how the pair are related to each other (Fabregas \& Scallse, 2012). Additionally, in Linguistics, Morphology refers to the mental system involved in word formation or to the branch of Linguistics that deals with words, their internal structure, and how they are formed (Aronoff \& Fudeman, 2001). Hence, Morphology is the way how the words are structured.

Inflection is called as 'relational makers' that is suitable for words which are used in Syntax. Brinton defined that inflectional affix in English is always a suffix, there may be only one in a word (Brinton, 2000). On other hand, inflection is added to a stem, which does not change the classes, but its distribution is then limited in the syntactic structure (Jackson \& Amvela, 2000). Hence, inflection is one of affix parts which can change form of the word without changing the meaning and the part of speech.

Derivation is the combination of a word stem with a grammatical morpheme, usually resulting in a word of a different class, often with a meaning hard to predict exactly (Jurafsky \& Martin, 2009). Meanwhile, derivation studies the principle governing the construction of new words, without reference to the specific grammatical role a word might play in a sentence (Crystal, 2005). To sum up, derivation is the word formation process which derivational suffix always attaches to the base word to create a new word.

The syntax of a language is described in terms of a taxonomy (i.e. classificatory list) of the range of different types of syntactic structures found in the language (Radford, 2004). Addintionally, Weschler (2015) explained that syntax may be defined as the grammatical system for combining words into utterances, so syntax in this broad sense includes phrase structure, morphosyntax, and compositional semantics. Hence, Syntax is the study which is related to how to arrange the words in the sentence recording to the setting that had been considered.

Sentence is a group of a words that you use to communicate your ideas in writing or in speech. It is complete, independent unit of thought, and consists of two main parts (Oshima \& Hogue, 1983). In grammatical study, this explanation becomes focused to an utterance that expresses a feeling or opinion, but refers to technical definition, it will become a grammatically self-contained speech unit of a word, or syntactically related group that express an statement, a question, a command, a wish, or an exclamation, which in writing usually begins with a capital letter and ends with a period, question mark, or punctuation mark (Nurlaili, 2015). Based on the explanation above, sentence is the way to express feelings or opinion in writing or a speeh.

A sentence can contain in one or more clause, a clause can contain in one or more phrase, a phrase can contain in one or more word, and a word can contain in one or more morpheme and morphemes are the minimal unit in the langauge. Clause as a sense the 'main' clause of the sentence (Husnton \& Francis, 2000). Additionally, every clause has at least a subject and a verb (Stilman, 2010). Hence, a clause is combination of words that consists of minimal one verb and one predicate, but in other case, a clause can consist of subject, predicate, object or adjunct and complement.

\section{RESEARCH METHODOLOGY}

This paper is done by conducting descriptive qualitative and content analysis research design (Cresswell, 2003; Cresswell, 2005). Both of them are the terms that are widely used to studies. Those are two methods for designing research. The source of data was article political news on Online Tempo in January, 2019. The major instrument of this research is the researchers themselves because she actively obtained and clustered the data and the secondary data was data sheet. Data were collected using the note method. The researchers chose political news only as one of the segments to be analyzed in this case. The data in this study were inflection, derivation, and clause structure in which inflection and derivation as the parts of 
Pertiwi Rini Nurdiani, Umar Fauzan

morphological study. Whereas clause structure is a branch of syntax study. The main instrument of this research is the researchers themselves because they actively obtained and gathered the data (Bogdan \& Biklen, 1982; Taylor, Bogdan, \& DeVault, 2016). The steps of collecting data were conducted in three ways. Firstly, finding the political news on Online Tempo in January, 2019. Secondly, choosing one article on the political Tempo news in January, 2019. Thirdly, reading all the contents of political news in Januray, 2019 that have chosen.

Moreover, the researchers analyzed the inflectional and derivational morphemes as study of Morphology through the steps such as; firstly, finding and listing all the word inflectional and derivational affixes and determining the clause structures on that political news on January, 2019. Secondly, finding out the word in the political news. This employed table to describe it. Thirdly, classifying the bases of roots in the politcal Tempo news on January, 2019 depend on their part of speech. Then analyzing the patterns of clause structure as the subject of syntax by determining the pattern of clause structure that is used in political Tempo news on January, 2019. The data analysis technique in this research used the interactive model namely data reduction, data display, conclusion and verification proposed by Miles \& Huberman, (1994) and Miles, Huberman, \& Saldana (2014).

\section{FINDINGS}

The purpose of this research is to analyze the types and patterns of derivational morpheme, inflectional morpheme and pattern of clause structure that found on political news. The findings of inflectional morpheme, derivational morpheme and pattern of sentence structure were as follows:

\subsection{The Patterns of Inflectional Morpheme}

Based on Brinton's theory, inflectional affixes is always a suffix, there may be only in a word (Brinton, 2000). Inflection is added to a stem, which does not change the classes, but its distribution is then limited in the syntactic structure (Jackson \& Amvela, 2000). To sum up, the inflection word is one of the morphology realms that related to grammatical language. It produces the different form of words. The classifications of inflectional morphemes that are found on article of political news of online Tempo in January 2019 are described as the table below:

Table 4.1 Inflectional Morphemes data

\begin{tabular}{|c|l|l|l|l|l|l|}
\hline No & Coding & $\begin{array}{c}\text { Inflected } \\
\text { Forms }\end{array}$ & \multicolumn{1}{|c|}{ Case } & Base Form & \multicolumn{1}{|c|}{ Case } & \multicolumn{1}{|c|}{ Meaning } \\
\hline 1 & 1 A.1 & Sa(i)-d & Past Participle & Say & $\begin{array}{l}\text { Present } \\
\text { Participle }\end{array}$ & To tell something \\
\hline 2 & 1 A.2 & Commit-ed & Past Participle & Commit & $\begin{array}{l}\text { Present } \\
\text { Participle }\end{array}$ & $\begin{array}{l}\text { Showing } \\
\text { commitment }\end{array}$ \\
\hline 3 & 1 A.3 & Politic-s & Plural & Politic & Singular & $\begin{array}{l}\text { relating to civil } \\
\text { government }\end{array}$ \\
\hline 4 & 1 A.4 & Region-s & Plural & Region & Singular & A tract of land \\
\hline 5 & 1 A.5 & Long-er & $\begin{array}{l}\text { Comparative } \\
\text { degree }\end{array}$ & Long & Adjective & $\begin{array}{l}\text { having much } \\
\text { distance or duration }\end{array}$ \\
\hline 6 & 1 A.6 & exist-s & $\begin{array}{l}\text { Verb for third } \\
\text { subject }\end{array}$ & Exist & $\begin{array}{l}\text { Present } \\
\text { Participle }\end{array}$ & Have being or reality \\
\hline 7 & 1 A.7 & Tr(i)-ed & Past Participle & Try & $\begin{array}{l}\text { Present } \\
\text { Participle }\end{array}$ & To attempt \\
\hline
\end{tabular}




\begin{tabular}{|c|c|c|c|c|c|c|}
\hline 8 & $1 \mathrm{~A} .8$ & Add-ed & Past Participle & Add & $\begin{array}{l}\text { Present } \\
\text { Participle }\end{array}$ & To join or unite \\
\hline 9 & $1 \mathrm{~A} .9$ & Focus-ed & Past Participle & Focus & $\begin{array}{l}\text { Present } \\
\text { Participle }\end{array}$ & $\begin{array}{l}\text { Concentration of } \\
\text { attention }\end{array}$ \\
\hline 10 & $1 \mathrm{~A} .10$ & Program-s & Plural & Program & Singular & $\begin{array}{l}\text { a set of structured } \\
\text { activities }\end{array}$ \\
\hline 11 & $1 \mathrm{~A} .11$ & Carr(i)-ed & Past Participle & Carry & $\begin{array}{l}\text { Present } \\
\text { Participle }\end{array}$ & $\begin{array}{l}\text { To take something to } \\
\text { another place }\end{array}$ \\
\hline 12 & $1 \mathrm{~A} .12$ & Problem-s & Plural & Problem & Singular & $\begin{array}{l}\text { A puzzling } \\
\text { circumstance }\end{array}$ \\
\hline 12 & $1 \mathrm{~A} .13$ & $\begin{array}{l}\text { Experienc- } \\
\text { ed }\end{array}$ & Past Participle & $\begin{array}{l}\text { Experienc } \\
\mathrm{e}\end{array}$ & $\begin{array}{l}\text { Present } \\
\text { Participle }\end{array}$ & $\begin{array}{l}\text { An event one has } \\
\text { happened }\end{array}$ \\
\hline 14 & $1 \mathrm{~A} .14$ & Farmer-s & Plural & Farmer & Singular & $\begin{array}{l}\text { A person who works } \\
\text { the land }\end{array}$ \\
\hline 15 & $1 \mathrm{~A} .15$ & Laborer-s & Plural & Laborer & Singular & $\begin{array}{l}\text { One who uses body } \\
\text { strength }\end{array}$ \\
\hline 16 & $1 \mathrm{~A} .16$ & $\begin{array}{l}\text { Housewi } \\
\text { (ve)-s }\end{array}$ & Plural & Housewife & Singular & $\begin{array}{l}\text { The wife of a } \\
\text { hou seholder }\end{array}$ \\
\hline 17 & $1 \mathrm{~A} .17$ & $\begin{array}{l}\text { Complaint- } \\
\text { s }\end{array}$ & Plural & Complaint & Singular & A difficulty \\
\hline 18 & $1 \mathrm{~A} .18$ & Resident-s & Plural & Resident & Singular & $\begin{array}{l}\text { A person, animal or } \\
\text { planting who living } \\
\text { at a certain location }\end{array}$ \\
\hline 19 & $1 \mathrm{~A} .19$ & $\begin{array}{l}\text { Complain- } \\
\text { ed }\end{array}$ & Past Participle & Complain & $\begin{array}{l}\text { Present } \\
\text { Participle }\end{array}$ & $\begin{array}{l}\text { To express feeling of } \\
\text { dissatisfaction }\end{array}$ \\
\hline 20 & $1 \mathrm{~A} .20$ & Long-est & Superlative & Long & Adjective & $\begin{array}{l}\text { having much } \\
\text { distance or duration }\end{array}$ \\
\hline 21 & $1 \mathrm{~A} .21$ & Import-s & Plural & Import & Singular & $\begin{array}{l}\text { Something for sale or } \\
\text { trade }\end{array}$ \\
\hline 22 & $1 \mathrm{~A} .22$ & $\begin{array}{l}\text { Indonesian- } \\
\mathrm{s}\end{array}$ & Plural & $\begin{array}{l}\text { Indonesia } \\
\mathrm{n}\end{array}$ & Singular & $\begin{array}{l}\text { A person who living } \\
\text { in or using language } \\
\text { of Indonesia }\end{array}$ \\
\hline 23 & $1 \mathrm{~A} .23$ & Affirm-ed & Past Participle & Affirm & $\begin{array}{l}\text { Present } \\
\text { Participle }\end{array}$ & $\begin{array}{l}\text { To agree or to assert } \\
\text { positively }\end{array}$ \\
\hline 24 & $1 \mathrm{~A} .24$ & Become-s & $\begin{array}{l}\text { simple present } \\
\text { tense }\end{array}$ & Become & $\begin{array}{l}\text { Present } \\
\text { Participle }\end{array}$ & Turn into \\
\hline 25 & $1 \mathrm{~A} .25$ & $\begin{array}{l}\text { Commidit(i } \\
\text { )-es }\end{array}$ & Plural & $\begin{array}{l}\text { Commodit } \\
\text { y }\end{array}$ & Singular & $\begin{array}{l}\text { Something useful or } \\
\text { valuable }\end{array}$ \\
\hline 26 & $1 \mathrm{~A} .26$ & Produce-d & Past Participle & Produce & $\begin{array}{l}\text { Present } \\
\text { Participle }\end{array}$ & To make something \\
\hline
\end{tabular}

The table above showed that there are 26 inflectional morphemes with 6 patterns that are found in article of political news on online Tempo in January 2019. 


\subsection{The Types and Patterns of Derivational Morpheme}

This section presented the generalization and discussion the types and patterns of derivational words that are used in article of political news on online Tempo in January 2019. Derivational affix has two patterns i.e. class-changing and class mantaining (Jackson \& Amvela, 2000). The two kinds of derivational words that are found in the article of political news on online Tempo in January 2019 are reported below:

\subsubsection{Class-Changing}

Class-changing derivational affixes can change the classes of the words if they are added to. Jackson proposed that class-changing derivational affixes change the word class of the word to which they are added (Jackson \& Amvela, 2000). Then class-changing derivations produce a derived form of another class (Robins, 2013). Thus, class-changing derivational affixes can change the classes of the words or part of the speech if they are added to.

Class-changing of derivational words that are found on article of political news of online Tempo in January 2019 are mostly suffixes than prefixes. The process of class-changing derivations are described in the table below:

Table 4.2.1 Class-Changing Derivation Data

\begin{tabular}{|c|c|c|c|c|c|c|c|c|}
\hline \multirow{2}{*}{ No } & \multirow{2}{*}{ Coding } & \multirow{2}{*}{$\begin{array}{l}\text { Derivation } \\
\text { words }\end{array}$} & \multicolumn{4}{|c|}{ Affix } & \multirow{2}{*}{ Base Word } & \multirow{2}{*}{ Meaning } \\
\hline & & & Prefix & Meaning & Suffix & Meaning & & \\
\hline 1 & $1 . \mathrm{B} 1$ & $\begin{array}{l}\text { According } \\
\text { (Adj) }\end{array}$ & & & -Ing & Agreeing & Accord $(\mathrm{N})$ & $\begin{array}{l}\text { To suit one } \\
\text { thing to } \\
\text { another }\end{array}$ \\
\hline 2 & 1B.2 & $\begin{array}{l}\text { Presidential } \\
\text { (Adj) }\end{array}$ & & & -ial & $\begin{array}{l}\text { Pertaining to a } \\
\text { president }\end{array}$ & $\begin{array}{l}\text { President( } \\
\text { N) }\end{array}$ & $\begin{array}{l}\text { The head of } \\
\text { state of a } \\
\text { republic }\end{array}$ \\
\hline 3 & 1B.3 & Election $(\mathrm{N})$ & & & -ion & $\begin{array}{l}\text { A process of } \\
\text { choosing } \\
\text { leader and } \\
\text { member of a } \\
\text { parliament }\end{array}$ & Elect (V) & $\begin{array}{l}\text { To choose a } \\
\text { candidate }\end{array}$ \\
\hline 4 & 1B.4 & $\begin{array}{l}\text { Productive } \\
\text { (Adj) }\end{array}$ & & & -ive & $\begin{array}{l}\text { Relation to the } \\
\text { creation of } \\
\text { goods or } \\
\text { service }\end{array}$ & $\begin{array}{l}\text { Product } \\
\text { (N) }\end{array}$ & A result \\
\hline 5 & 1B.5 & $\begin{array}{l}\text { Reflection } \\
(\mathrm{N})\end{array}$ & & & -ion & $\begin{array}{l}\text { Careful } \\
\text { thought }\end{array}$ & Reflect (V) & To bend back \\
\hline 6 & 1B.6 & $\begin{array}{l}\text { Competition } \\
\text { (N) }\end{array}$ & & & -ion & $\begin{array}{l}\text { A contest for a } \\
\text { prize or award }\end{array}$ & $\begin{array}{l}\text { Compete } \\
\text { (V) }\end{array}$ & $\begin{array}{l}\text { To take part in } \\
\text { a contest }\end{array}$ \\
\hline 7 & 1B.7 & $\begin{array}{l}\text { Delivering } \\
(\mathrm{N})\end{array}$ & & & $-\operatorname{Ing}$ & $\begin{array}{l}\text { To send } \\
\text { something or } \\
\text { shipping }\end{array}$ & $\begin{array}{l}\text { Deliver } \\
\text { (V) }\end{array}$ & $\begin{array}{l}\text { To bring } \\
\text { something to } \\
\text { its destination }\end{array}$ \\
\hline 8 & $1 \mathrm{~B} .8$ & $\begin{array}{l}\text { Eonom(-ic) } \\
\text { (Adj) }\end{array}$ & & & $-i c$ & $\begin{array}{l}\text { Pertaining to } \\
\text { an economy }\end{array}$ & $\begin{array}{l}\text { Economy } \\
\text { (N) }\end{array}$ & $\begin{array}{l}\text { Representing } \\
\text { good value for } \\
\text { money }\end{array}$ \\
\hline 9 & $1 \mathrm{~B} .9$ & $\begin{array}{l}\text { Especially } \\
\text { (Adv) }\end{array}$ & & & $-l y$ & $\begin{array}{l}\text { Used to place } \\
\text { greater } \\
\text { emphasis upon } \\
\text { someone or } \\
\text { something }\end{array}$ & $\begin{array}{l}\text { Especial } \\
\text { (Adj) }\end{array}$ & $\begin{array}{l}\text { Exceptional in } \\
\text { Important }\end{array}$ \\
\hline 10 & $1 \mathrm{~B} .10$ & $\begin{array}{l}\text { Government } \\
\text { (N) }\end{array}$ & & & -ment & $\begin{array}{l}\text { Enforce laws } \\
\text { to control a } \\
\text { country }\end{array}$ & $\begin{array}{l}\text { Govern } \\
\text { (V) }\end{array}$ & $\begin{array}{l}\text { To exercise a } \\
\text { political } \\
\text { authority }\end{array}$ \\
\hline
\end{tabular}

The table above showed that there were 10 derivational words with 3 patterns such as noun to adjective, adjective to adverb and verb to noun of class-changing found in article of political news on online Tempo in January 2019. 


\subsubsection{Class-Mantaining}

Class mantaining derivation is derivation of new lexemes which are of the same from class as the base which they are formed (Bauer, 1983). Class-mantaining derivational affixes change the meaning of derivate which most prefixes and a few suffxes belong to this category. In other word, class-mantaining derivational affix is a process that can change the meaning of a word without changing a class of a word.

In class-mantaining derivational words that are found on article of political news of online. Tempo in January 2019 is a prefix. The process of class-changing derivational affix could be described as the table below:

Table 4.2.2 Class-Mantaining Derivation Data

\begin{tabular}{|c|c|c|c|c|c|c|c|c|}
\hline \multirow{2}{*}{$\begin{array}{l}\mathrm{N} \\
\mathrm{o} .\end{array}$} & \multirow{2}{*}{$\begin{array}{l}\text { Codi } \\
\text { ng }\end{array}$} & \multirow{2}{*}{$\begin{array}{l}\text { Derivation } \\
\text { word }\end{array}$} & \multicolumn{4}{|c|}{ Affix } & \multirow{2}{*}{$\begin{array}{c}\text { Base } \\
\text { Word }\end{array}$} & \multirow{2}{*}{ Meaning } \\
\hline & & & Prefix & Meaning & Suffix & Meaning & & \\
\hline 1 & 1C.1 & $\begin{array}{l}\text { Non- } \\
\text { Nahdatul } \\
\text { Ulama (N) }\end{array}$ & Non- & $\begin{array}{l}\text { People who do not } \\
\text { contribute in an } \\
\text { organization }\end{array}$ & & & $\begin{array}{l}\text { Nahdatul } \\
\text { Ulama (N) }\end{array}$ & $\begin{array}{l}\text { An } \\
\text { organization } \\
\text { of Muslim }\end{array}$ \\
\hline
\end{tabular}

The table above showed that there was only 1 derivational word with 1 pattern of classmantaining found in article of political news on online Tempo in January 2019.

\subsection{The Pattern of Clause Structure}

Clause as a sense the 'main' clause of the sentence (Husnton \& Francis, 2000). Additionally, every clause has at least a subject and a verb (Stilman, 2010). Hence, a clause is combination of words that consists of minimal one verb and one predicate. But in the other case, a clause can consist of subject, predicate, object or adjunct and complement.

The patterns of clause structure that are found on article of political news of online Tempo in January 2019 are described in the table below:

Table 4.3 Pattern of Clause Strucure Data

\begin{tabular}{|c|c|c|c|}
\hline No. & Coding & The Patterns & Clauses \\
\hline 1 & $2 \mathrm{~A} .1$ & $\mathrm{~S}-\mathrm{V}$ & $\begin{array}{l}\text { 1. The identity politics has begun to diminish. } \\
\text { 2. He said }\end{array}$ \\
\hline 2 & $\begin{array}{l}\text { 2B. } 2 \\
\text { 2B.3 } \\
\text { 2B.4 }\end{array}$ & $\mathrm{S}-\mathrm{V}-$ to $\operatorname{Inf}$ & $\begin{array}{l}\text { 1. Presidential and vice Presidential } \\
\text { candidate pair number } 02 \text { bad committed not to use identity } \\
\text { politics in the } 2019 \text { presidential election. } \\
\text { 2. Prabowo-Sandi will always campaign to voice a productive } \\
\text { vision and mission. } \\
\text { 3. His camp tried to avoid identity politics. } \\
\text { 4. They will try to reduce the import of commodities }\end{array}$ \\
\hline 3 & $\begin{array}{l}2 \mathrm{CC} .1 \\
2 \mathrm{C} .2 \\
2 \mathrm{C} .3\end{array}$ & $\mathrm{~S}-\mathrm{V}-\mathrm{DO}$ & $\begin{array}{l}\text { 1. I accompany pak Prabowo and bang Sandi to the regions } \\
\text { 2. They won the } 2019 \text { presidential election. } \\
\text { 3. We visit the regions }\end{array}$ \\
\hline 4 & $2 \mathrm{D} .1$ & $S-V-$ Adjunct & 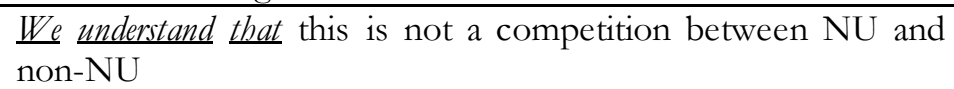 \\
\hline 5 & $\begin{array}{l}2 \mathrm{E} .1 \\
2 \mathrm{E} .2\end{array}$ & $\mathrm{~S}-$ be $\mathrm{V}-\mathrm{PN}$ & $\begin{array}{l}\text { 1. Many farmers complained about the government. } \\
\text { 2. The economic problems are the answer to the problems } \\
\text { experienced by people. }\end{array}$ \\
\hline 6 & $\begin{array}{l}2 \mathrm{~F} .1 \\
2 \mathrm{~F} .2\end{array}$ & $\mathrm{~S}-$ be $\mathrm{V}-\mathrm{PA}$ & $\begin{array}{l}\text { 1. Indonesia is the country with the longest coastline in the } \\
\text { world. } \\
\text { 2. Prabowo and Sandiaga would be more focused. }\end{array}$ \\
\hline 7 & $2 \mathrm{G} .1$ & $\mathrm{~S}-\mathrm{LV}-\mathrm{PN}$ & Prabowo-Sandiaga becomes president and vice president. \\
\hline
\end{tabular}


Pertiwi Rini Nurdiani, Umar Fauzan

Based on the table above, there are 7 patterns of clause structure that are found in political news article. Those are $S-V, S-V-$ to Inf, $S-V-D O, S-V-A d j, S-b e V-P N, S$ - be $V-P A$, abd $S-L V-P N$.

\section{DISCUSSIONS}

Based on the research, inflectional morphemes are commonly used instead of derivational words. The researchers found that 26 inflectional words appeared in one political news article of online Tempo in January 2019. Inflection is always marked by suffixation which this argument is in line with Brinton's statement that inflectional affix in English is always a suffix, there may be only one in a word (Brinton, 2000). There are 5 patterns that are used in one political news article of online Tempo in January 2019, that are present participle changing to the past participle, present participle changing to the verb for third subject, singular changing to the plural, adjective changing to the comparative and adjective changing to the superlative.

There are 10 words in changing present participle to the past participle. There are 11 words for the changing of singular to the plural. There is one word for the changing of adjective to comparative degree. There are 2 words for the changing of present participle to verb of third subject and 1 word for the changing of adjective to superlative. From the explanation above, the most common used pattern of the article is the pattern of singular changing to plural.

Based on the research finding, inflectional morpheme is the process that can change the form of word without changing the meaning and the part of speech of word. Inflectional words can not change the class of words, but its distribution is then limited in the syntactic structure (Brinton, 2000). Hence, inflection word is highly related to English grammar.

The previous study which is accomplished by Endang (2014), analyzed that there are 33 data belonging to inflectional suffix with 3 patterns. The patterns that are used in songs lyrics of Adele albums are verbal suffix meaning ( $-s,-i n g,-e d)$, noun suffixes (-s (plural)), and adjective suffixes $(-e r,-e s t)$. Therefore, the previous studies and this research had similar findings, especially in the use of patterns of inflection that are used on the subject of the study.

For derivational morphemes, researchers found two types of derivational words i.e. classchanging and class-mantaining. Class-mantaining is characterized by prefixation, then classchanging is characterized by suffixation (Bauer, 1983). However, in this research, researchers found 3 patterns of class-changing and 1 pattern of class-mantaining that are found on one political news article of online Tempo in January, 2019. It means that the changing of wordclass brings a great effect than in the same word-class that is found on a political news article.

In this research, the researchers found 3 patterns of class-changing derivational words that are found in a political news of online Tempo in January 2019. There are 4 words of noun to adjective, 5 words of verb to noun and one word adjective to adverb. The finding showed that the most used pattern was the changing of verb to noun with 5 words that were used in types of class-changing that were found in the article. Based on that finding, it showed that suffixation had a big contribution in order to form derivational word rather than prefix.

Jackson \& Amvela (2000) stated that there were 8 patterns of class-changing derivation, but the researchers only found 3 patterns of class-changing in an article of political news on online Tempo in January 2019. Those were noun to adjective, verb to noun, and adjective to adverb. While the 8 patterns of class-changing derivation were verbs to noun, adjective to noun, noun to verb, adjective to verb, noun to adjective, verb to adjective, adjective to adverb, and noun to adverb. Thus, there are only some patterns found in an article of political news on online Tempo in January 2019.

The class-mantaining derivations could not change the class of words, but it could change the meaning of words. English class-mantaining derivations are mainly prefix (Jackson \& Amvela, 2000) than suffix. Based on Amvela and Jackson, class-mantaining derivations are divided into 3 patterns, those are noun to noun, verb to verb, and adjective to adjective (Jackson \& 
Amvela, 2000). Based on research finding, the researchers found one pattern of classmantaining in this research, it is noun to noun.

This research did not identify all of the patterns of word-class, the researchers merely found 3 patterns of class-changing such as noun to adjective, verb to noun, and adjective to adverb that are found in an article of political news. Mashlahatulammah, as previous researcher who has conducted the same research found that all of the types and patterns that commonly used is class-changing derivational words was in the pattern of adjective to adverb with 31 derivational words appear in the jurnal article of "Dinamika Ilmu" (Mashlahatulammah, 2018). In another previous study that was written by Aryati found the base adverb is the most word found in the Land of Five Towers Novel (Aryati, 2014).

Based on these research findings, the researchers also found the suffixes mostly indicated in an article of political news. Suffix that is commonly used in class-changing derivations in this research is verb to noun formation. Therefore, the previous studies and this research had some differences and similarities related to English derivations.

In the pattern of sentence structure finding, the researchers found some patterns of clause structure that were used in a political news article of online Tempo in January 2019. Clause as a sense the 'main' clause of the sentence (Husnton \& Francis, 2000). Additionally, every clause has at least a subject and a verb (Stilman, 2010; Koopman, Sportiche, \& Stabler, 2003). Hence, a clause is combining of words that consist minimal one verb and one predicate (Francez \& Koontz-Garboden, 2017).

According to Husnton \& Francis (2000), there are 7 patterns of clause structure which generally is found, those are Verb-Object-Object, Verb-Object Complement, Verb-Adjunct, Verb-2 Objects, Verb-Verb-ing-Object, Verb-to Infinitive with another kind of verb, and Verbto Infinitive (as Adjunct). Additionally, Vitto proposed that there are 10 patterns that can be used in clause structure, S-V, S-be-PA, S-be-PN, S-LV-PN, S-LV-PA, S-IV, S-TV-DO, S-TVIO-DO, S-TV-DO-N, and S-TV-DO-Adj. Hence, total of patterns of clause structure that can be measured to this research is 17 patterns.

However in these findings, the researchers found 7 patterns of clause structure on the article. There are 4 clauses used $S$ - $V$-to Infinitive pattern, 3 clauses used $S$ - $V$-DO pattern, 2 clauses used $S$-be $V$-PN pattern, 2 clauses used $S$-be $V$-PA, 2 clauses used $S$ - $V$ pattern. 1 clause used $S-L V-P N$ pattern and 1 clause used $S-V-A d j-C$ pattern. In conclusion, the most common pattern used of clause structure patterns that is found on a news political article of online Tempo in January 2019 is $S$ - $V$-to Infinitive pattern.

In the previous study that has conducted by Wulandari, she found 5 patterns in 52 cases in her thesis. In sentence pattern $1(\mathrm{~N}-\mathrm{V})$ consisted of 12 cases, there are 19 cases in pattern 2 $(\mathrm{N}-\mathrm{V}-\mathrm{N})$, there are 7 cases in pattern $3(\mathrm{~N}-\mathrm{LV}-\mathrm{N})$, there were 10 cases in pattern 4 (N-LV-Adj), and there were 4 cases in pattern 5 . The most dominant sentence pattern that was found in Wulandari's thesis entitled "The Analysis of Basic Sentence Pattern in English Translation of the Holy Qur'an in Surah Ad Dukhan by Abdulloh Yusuf Ali" was sentence pattern $2(\mathrm{~N}-\mathrm{V}-\mathrm{N})$ (Wulandari, 2015). Based on the previous study, this research has similarities and differences related to this study, especially in syntax field.

\section{CONCLUSION}

This research has discussed the analysis of the types and patterns of inflectional morphemes, derivational morphemes, and clause structures used in an political news article of online Tempo in January 2019. The patterns of inflectional morphemes that are found in an political newarticle are 5 patterns. Those are present participle changing to the past participle (10 words), present participle changing to the verb for third subject (2 words), singular changing to the plural (12 words), adjective changing to the comparative (1 word) and adjective changing to the superlative (1 word). Thus, the pattern of singular changing to the plural is the dominant pattern of inflectional 
Pertiwi Rini Nurdiani, Umar Fauzan

morpheme used in an political news article of online Tempo in January 2019. There are two types of derivational morphemes, those are class-changing and class-mantaining derivations. Each type consists of some patterns. The most common type of derivations is class-changing with 3 patterns, instead of class-maintaining only 1 pattern. The most common pattern of derivational morpheme is class-changing pattern (verb to noun) with 5 derivational words that appeared in an political news article of online Tempo in January 2019. The patterns of clause structure that are found in the article are 7 patterns. There are 4 clauses used $S$ - $V$-to Infinitive pattern, 3 clauses used $S$ - $V$-DO pattern, 2 caluses used $S$-be $V$-PN pattern, 2 clauses used $S$-be $V$ $P A, 2$ clauses used $S$ - $V$ pattern, 1 clause used $S-L V$-PN pattern and 1 clause used $S$ - $V$-Adj-C pattern. In conclusion, the most common pattern used of clause structure pattern that is found on a news political article of online Tempo in January 2019 is $S$ - $V$-to Infinitive pattern.

\section{REFERENCES}

Ado, M. A., \& Bidin, S. J. (2017). Morphological Description of Noun Formation Process: Case of Suffixation and Prefixation in Iguta Language. ASLAN TEFL: Journal of Language Teaching and Applied Linguistics, 2(1), 17-40. https://doi.org/10.21462/asiantefl.v2i1.26

Akan, M. F., Hassan, H. M. A., Islam, A. B. M. S., \& Abdelmajd, A. E. M. (2017). The Utility Extent of Linguistics to Language Teaching: An Experimental Evaluation. JELTL: Journal of English Language Teaching and Linguistics, 2(1), 65-73. https://doi.org/10.21462/jeltl.v2i1.42

Aronoff, M., \& Fudeman, K. (2001). What is Morphology? Oxford: Blackwell Publishing.

Aryati, M. S. (2014). An Analysis of Derivational Affixes in the Land of Five Towers Novel by A. Fuadi Translated by Angie Kilbame. UMS.

Bauer, L. (1983). English Word-Formation. Cambridge: Cambridge University Press.

Bellomo, T. S. (2009). Morphological analysis and vocabulary development: Critical criteria. The Reading Matrix, 9(1), 44-55. Retrieved from http://www.readingmatrix.com/articles/bellomo/article.pdf

Bogdan, R. C., \& Biklen, S. . (1982). Qualitative research for education: An introductory to theory and methods. Boston: Allyn and Bacon, Inc.

Brinton, L. J. (2000). The Structure of Modern English: A Lingusistic Introduction. Amsterdam: John Benjamin Publishing Company.

Briones, R. R. Y. (2016). Textual Analysis through Systemic Functional Linguistics. Journal of English Language Teaching and Linguistics, 1(2). https:/ / doi.org/10.21462/jeltl.v1i2.27

Budiharto, R. A. (2014). A Morphosyntactic Analysis on the University Students' Thesis Proposal in Madura. Univerity Madura.

Caesar, R. O. (2019). A Morphosyntactic Analysis of Dangme Allusive Names. Journal of Universal Language, 20(2), 53-93. https://doi.org/10.22425/jul.2019.20.2.53

Chomsky, N. (1976). Syntactic Structures (12th ed.). Paris: The Hague Publisher.

Chomsky, N. (2006). Language and Mind (3rd ed.). New York: Cambridge University Press.

Cresswell, J. (2003). Research Design, Qualitative, Quantitative, and Mixed Method Approach (2nd ed.). California: Sage Publications.

Cresswell, J. (2005). Research Design: Qualitative and Quantitative Approaches. London: Longman.

Crystal, D. (2005). How Language Works. New York: Penguin Book.

Darmawansah, D., \& Indartono, S. (2019). The Influence of Instructional Syntax to Engage EFL Students in Online Learning Environment. Indonesian Journal of English Language Teaching and Applied Linguistics, 4(1), 1-9. https://doi.org/.1037//0033-2909.I26.1.78

Dita, S. N. (2010). A Morphosyntactic Analysis of the Pronominal System of Philippine Languages. PACLIC 24 - Proceedings of the 24th Pacific Asia Conference on Language, Information and Computation, 45-59. 
Dryer, M. (2008). Word Order in Tibeto-Burman Languages. Linguistics of the Tibeto-Burman Area, $31(1)$.

Endang, S. N. (2014). The Analysis of Derivational and Inflectional Morphemes in Lyric of Songs Adele Albums. Muhammadiyah University of Surakarta.

Fabregas, A., \& Scallse, S. (2012). Morphology from Data the Theories. Edinburgh: Edinburgh University Press.

Finch, G. (2000). Linguistic Terms and Concepts. New York: St. Martin's Press.

Francez, I., \& Koontz-Garboden, A. (2017). Semantics and Morphosyntactic Variation: Qualities and the Grammar of Property Concepts. In Semantics and Morphosyntactic Variation. https://doi.org/10.1093/acprof:oso/9780198744580.001.0001

Goryainova, M., Grouin, C., Rosset, S., \& Vasilescu, I. (2014). Morpho-syntactic Study of Errors from Speech Recognition System. Proceedings of the 9th International Conference on Language Resources and Evaluation, LREC 2014, 3045-3049.

Hijjo, N. F. . (2013). A morphosyntactic Analysis on Malaysian Secondary School Students' Essay Writing in English Class. International Journal of Humanities and Social Science, 3(11).

Husnton, S., \& Francis, G. (2000). Pattern Grammar: A Corpus-Driven Approach to the Lexical Grammar of English. Amsterdam: John Benjamin Publishing Company.

Irmayani, I., \& Rachmajanti, S. (2017). Lexical Features of Teacher Talk in English Classrooms in Senior High Schools. Dinamika Ilmu, 17(1), 59-70. https://doi.org/10.21093/di.v17i1.639

Jackson, H., \& Amvela, E. Z. (2000). Words, Meaning and Vocabulary: An Introduction to Modern English Lexicology. New York: Continuum International Publishing.

Jurafsky, D., \& Martin, J. H. (2009). Speech and Language Processing: An Introduction to Natural Language Processing, Computational Language, and Speech Recognition. New Jersey: Prentice Halls.

Kenstowicz, M. (2005). Verbal Tone in Buli: A Morphosyntactic Analysis. Cross-Linguistic Study of Tonal Phenomena, (December), (1-14).

Koopman, H., Sportiche, D., \& Stabler, E. (2003). An Introduction to Syntactic Analysis and Theory. Unpublished Manuscript, (April), 246. Retrieved from http:// citeseerx.ist.psu.edu/viewdoc/download?doi=10.1.1.122.5914\&amp;rep=rep1\&am p;type $=$ pdf

Lyon, J. (2002). Language and Linguistics. Cambridge: Cambridge University Press.

Mainingrum, H. (2018). Morphosyntactical Analysis of African Vernacular English in Moonlight Movie. Diponegoro University.

Mammeri, S. (2015). A Morphosyntactic Study of EFL Students' Written Compositions: A Corpus Based Analysis. Arab World English Journal, August, 84-91.

Mashlahatulammah, M. (2018). An Analysis od Derivational Affixes in a Journal Article of Dinamika Ilmu. State Islamic Institute of Samarinda.

Miles, M. B., \& Huberman, A. M. (1994). Qualitative Data Analysis (2nd ed.). California: Sage Publications.

Miles, M. B., Huberman, A. M., \& Saldana, J. (2014). Qualitative Data Analysis: A Methods Sourcebooks (3rd ed.). California: SAGE Publications, Inc.

Miller, J. (2002). An Introduction to English Syntax. Edinburgh: Edinburgh University Press.

Nurhayati, D. A. W., Djatmika, D., Santosa, R., \& Wiratno, T. (2017). Effect of Students' Term and Educational Institution on the Arising of Indonesian Morphology-Syntactical Interference in ELLT. Dinamika Ilmu, 17(1), 101. https:/ / doi.org/10.21093/di.v17i1.739

Nurlaili, R. F. (2015). Syntactical Error Analysis, in Second Semester Student's Writing of IAIN Tulung Agung. IAIN Tulungagung.

Ojanga, J. A. (2015). Analysis of the Morphosyntactic Structure of Uettarances in Dholuo/ Kiswabili Codeswitching. Egerton University.

Oshima, A., \& Hogue, A. (1983). Writing Academic English - A Writing and Sentence Structure 
Pertiwi Rini Nurdiani, Umar Fauzan

Workbook for International Students. New York: Addison-Wesley Publishing Company Inc.

Parisse, C., \& Normand, M. T. L. (2000). How Children Build Their Morphosyntax: The Case of French. Journal of Child Language, 27.

Putri, R. M. (2017). An Analysis of Derivation in Short Story Used by The Jakarta Post Online in 2017. State Islamic Institute of Samarinda.

Radford, A. (2004). English Syntax: An Introduction. Cambridge: Cambridge University Press.

Rashel, M. M. (2010). Morphosyntactic Analysis of Mro Language. Dhaka University Journal of Linguistics, 2(3), 141-160. https://doi.org/10.3329/dujl.v2i3.4149

Robins, R. H. (2013). General Lingusitics (4th ed.). New York: Routledge.

Setyawan, Y. B. (2014). A Morphological Study on Affixes in English Song Lyrics on the Resistance Album Composed by Muse. Muhammadiyah University of Surakarta.

Shu, C. H. (2012). Towards a Morphosyntactic Analysis of Mandarin Mood/Aspect Marker ge. Language and Linguistics, 13(4), 663-692.

Stilman, A. (2010). Grammatically Correct (2nd ed.). New York: Writer Diggest Books.

Sundari, H., \& Febriyanti, R. H. (2020). Syntactical Development on Second Language Writing: A Case of L2 Child Learner on Immersion Experience Abroad. IJELTAL (Indonesian Journal of English Language Teaching and Applied Linguistics), 4(2), 245. https://doi.org/10.21093/ijeltal.v4i2.469

Taylor, S. J., Bogdan, R., \& DeVault, M. L. (2016). Introduction to Qualitative Research Methods : a Guidebook, and Resource (4th ed.). New Jersey: John Wiley \& Sons, Inc.

Weschler, S. (2015). Word Meaning and Syntax: Approaches to the Interface. Oxford: Oxford University Press.

Wulandari, A. (2015). The Analysis of Basic Sentence Pattern in English Translation of the Holy Qur'an in Surah Ad Dukhan by Abdulloh Yusuf Ali. Register Journal, 8(2). 